\title{
Initial development of peach rootstock genotypes propagated by herbaceous cuttings
}

\author{
João Alison Alves Oliveira ${ }^{1}$, Danielle Fabíola Pereira da Silva², Cláudio Horst Bruckner ${ }^{3}$, \\ Francielly Rodrigues Gomes ${ }^{4}$, Angelita Lorrayne Soares Lima Ragagnin ${ }^{5}$, Hildeu Ferreira da Assunção ${ }^{6}$
}

Abstract - The peach tree is a temperate fruit tree propagated by grafting with the scion cultivar and the rootstock from seeds, generating low uniformity, a viable alternative is propagation by herbaceous cuttings. The objective of this study was to evaluate the performance of different genotypes of peach rootstock propagated by herbaceous cuttings. The experiment was carried out with standardized cuttings of $15 \mathrm{~cm}$ in length treated with $3,000 \mathrm{mg} \mathrm{L}^{-1}$ of IBA solution, then were transplanted into $3 \mathrm{~L}$ polyethylene bags. A completely randomized design with five replications was adopted, each plot consisting of three plants. Sixteen peach genotypes from UFV breeding program were tested: 713-3, 713-6, 713-7, 713-10, 813-2, 813-3, 813-5, 813-15, 913-3, 913-6, 913-11, 913-17, C6, C7 and C8. After 80 days the following parameters were evaluated: stem length $(\mathrm{cm})$, stem diameter $(\mathrm{mm})$ and internode length $(\mathrm{cm})$. Data were subjected to analysis of variance by the $\mathrm{F}$ test and averages compared by the Scott-Knott test at a 5\% probability level with the GENES statistical software. It can be concluded that the lower initial development was observed in genotype 1113-11 and the highest initial development was from genotypes 713-13 and 813-5.

Index terms: Prunus persica (L); plant production; indolbutyric acid.

\section{Desenvolvimento inicial de genótipos de porta-enxertos de pessegueiro propagados por estaquia herbácea}

\section{Corresponding author: fram_rodgomes@hotmail.com}

Received: November 27, 2019. Accepted: April 06, 2020.

Copyright: All the contents of this journal, except where otherwise noted, is licensed under a Creative Commons Attribution License.

\section{(cc) $\mathbf{E Y}$}

Resumo - O pessegueiro é uma fruteira de clima temperado, propagada por meio de enxertia com a cultivar copa e o porta enxerto oriundo de sementes, o que resulta em reduzida uniformidade, sendo a propagação por estaquia herbácea uma alternativa viável. Objetivou-se avaliar o desempenho de diferentes genótipos de porta-enxerto de pessegueiro propagados por estaquia herbácea. $\mathrm{O}$ experimento foi realizado utilizando-se de estacas padronizadas em $15 \mathrm{~cm}$ de comprimento, tratadas em solução de AIB, na concentração de $3.000 \mathrm{mg} \mathrm{L}^{-1}$ que, posteriormente, foram transplantadas para embalagens de polietileno com capacidade para 3 L. Adotou-se o delineamento experimental inteiramente casualizado, com cinco repetições, sendo cada parcela composta por três plantas. Foram testados 16 genótipos de pessegueiro oriundos do programa de melhoramento genético da UFV: 713-3; 713-6; 713-7; 713-10; 813-2; 813-3; 813-5; 813-15;913-3;913-6; 913-11; 913-17;C6; $\mathrm{C} 7$ e C8; e após 80 dias, foram avaliados os parâmetros: comprimento de haste (cm), diâmetro de haste $(\mathrm{mm})$ e comprimento de entrenós $(\mathrm{cm})$. Os dados foram submetidos à análise de variância, pelo teste F; e as médias, comparadas pelo teste Scott-Knott, ao nível de 5\% de probabilidade, com o auxílio do programa estatístico GENES. Conclui-se que o menor desenvolvimento inicial foi obtido no genótipo 1113-11, e as maiores estacas foram obtidas nos genótipos 713-13 e 813-5. Termos para indexação: Prunus persica (L); produção de mudas; ácido indolbutiríco.

\footnotetext{
${ }^{1}$ Agronomist, PhD, Professor at Federal Institute of Education, Science and Technology of Goiás - Posse - GO, Brazil. E-mail: joao.alison@ yahoo.com.br (ORCID: 0000-0003-3821-7507)

${ }^{2}$ Agronomist, PhD, professor at Federal University of Jataí, Jataí - GO, Brazil. E-mail: daniellefpsilva@ufg.br - CNPq productivity Scholarship (ORCID: 0000-0001-7366-5650)

${ }^{3}$ Agronomist, PhD, professor at Federal University of Viçosa, Viçosa - MG, Brazil. E-mail: bruckner@ufv.br (ORCID: 0000-0002-6249-3686) ${ }^{4}$ Agronomist, master in Agronomy (plant production), Federal University of Jataí, Jataí - GO, Brazil. E-mail: fram_rodgomes@hotmail.com
(ORCID: 0000-0001-7282-0719)

${ }^{5}$ Agronomist, master's degree student in Agronomy (plant production), Federal University of Jataí, Jataí - GO, Brazil. E-mail: angelitaragagnin@ gmail.com, CNPq Scholarship (ORCID: 0000-0002-5115-2704)

${ }^{6}$ Agronomist, PhD, Professor at Federal University of Jataí, Jataí - GO, Brazil. E-mail: hildeu@yahoo.com.br - CNPq Productivity Scholarship in Technological Development and Innovative Extension (ORCID:0000-0002-4203-6568)
} 
Brazil has ideal climatic conditions for the production of various fruit trees, including temperate species, commonly produced in the South and Southeast (ROSA et al., 2017a). Peach tree crop (Prunus persica L.) is widely used in family farming and generates direct and indirect jobs in both industry and commerce (GONÇALVES et al., 2019). The productivity and quality of the fruits may be related to the production of quality seedlings (MAYER et al., 2014), being the quality of the rootstock a limiting factor for the high vigor seedlings production and fruit yield (ROSA et al., 2017b).

The peach tree is propagated by grafting with the scion cultivar over the rootstock from seeds, however, the use of seeds increases genetic variability among the seedlings, making the propagation of the rootstocks by cuttings a viable practice, leading to production of clonal uniform seedlings with the same characteristics to the stock plant (TOMAZ et al., 2016). In addition to avoiding genetic variability, propagation of the rootstock by cuttings is viable because it is easy to perform and reduces the time required for seedling production (ROSA et al., 2017b).

Vegetative propagation by cuttings is made by the removal of parts of the stock plant to make a new complete plant by adventitious rooting induction (FERRIANI et al., 2008). This technique allows the shortly obtentions of commercial orchards with high genetic potential, because it ensure that the stock plant features are maintained, generating uniformity, precocity and high fruit quality (LATTUADA et al., 2011).

The rooting capacity of the cuttings can be increase with the use of PGR (Plant Growth Regulators) (TIMM et al., 2015). Auxin is an endogenous PGR that has an important function in rooting, but, depending on the physiologic or genetic conditions of the cuts and on the period of the year the levels of auxin can be low or scarce, being necessary exogenous auxins application, like indolbutyric acid (IBA) (PIZZATTO et al., 2011).

The part of the plant that is used is also a factor to be considered on peach tree propagation, once herbaceous cuttings have a smaller lignification degree, that allows the transport of substances, plus, herbaceous cuttings have high levels of auxin, favoring the rooting and development of the cuttings (ROSA et al., 2017b).

The rootstock influence on yield, on characters of the scion cultivar and also on the adoption of cultural practices like density, pruning, thinning and harvest, reason why the study of different genotypes of peach becomes extremely important (SCHMITZ et al., 2012). Based on the presented, the aim of this study was to evaluate the initial development of different genotypes of peach rootstock propagated by herbaceous cuttings.

The experiment was conducted in a greenhouse located in Teaching, Research and Extension Unit of Federal University of Viçosa $\left(20^{\circ} 45^{\prime} 26^{\prime \prime}\right.$ South Latitude and $42^{\circ} 52^{\prime} 08^{\prime \prime}$ 'West Longitude and $638 \mathrm{~m}$ of altitude).
The region climate is of the type Cwa, with annual average temperature of $19^{\circ} \mathrm{C}$ and rainfall index of $1,314 \mathrm{~mm}$ per year.

For the propagation of rootstocks of peach (Prunus persica L.), were used $15 \mathrm{~cm}$ length apical cuttings without the apical meristem and with a couple of leaves, treated with indolbutyric acid (IBA) at $3,000 \mathrm{mg} \mathrm{L}^{-1}$ concentration for five seconds, which had shown to be efficient in preliminary studies. The cuttings were collected from a single stock plant for each genotype in winter season, obtained from the middle and apical portions of the plant and wrapped in plastic boxes $(36.5 \times 26.5 \times 9.5 \mathrm{~cm})$ with sand, with a depth of 4 to $5 \mathrm{~cm}$ and kept on intermittent fogging for 49 days, with timer programmed to be triggered for 5 seconds, in time interval of 3.5 minutes.

After the rooting, were transplanted to polyethylene bags with capacity for $3 \mathrm{~L}$ and the dimensions of $30 \mathrm{x}$ $25 \times 20 \mathrm{~cm}$, with a mixture of ravine soil, washed sand and organic matter (tanned corral manure) in volumetric proportion $(2: 1: 1)$. It was made a specific fertilization for seedlings production (Osmocote ${ }^{\circledR}$ ), 30 days after transplant, in the dosage of $6 \mathrm{~g} / \mathrm{plastic}$ bag, of formulation 15-10-10+ micronutrients.

The cuttings were selected based on the selection index of Mulamba and Mock (1978), according to results obtained in a previous study (OLIVEIRA et al., 2018). Plants were conducted in single rod, being staking with bamboo stakes of $70 \mathrm{~cm}$ length, which were fixed on substrate near to rootstock and tied with cotton string, when required.

The experimental design used was the completely randomized, with five repetitions and eight cuttings for replication, being each plot composed by three plants. Were tested 16 genotypes of peach: 713-3, 713-6, 7137, 713-10, 813-2, 813-3, 813-5, 813-15, 913-3, 913-6, 913-11, 913-17, C6, C7 and C8 from the UFV breeding program.

After 80 days of the cuttings transplant, the parameter was evaluated: stem length (measuring since the insertion on the original cutting to the apical meristem), whose results were expressed in $\mathrm{cm}$, stem diameter, expressed in $\mathrm{mm}$ (measured at $5 \mathrm{~cm}$ of the original cutting) and length of internodes, expressed in $\mathrm{cm}$.

The data were submitted to variance analysis by the test F, and the averages were compared by test of ScottKnott, at level of $5 \%$ of probability, through the statistical software GENES (CRUZ, 2016).

Among the evaluated rootstock genotypes, 713-10, 713-13 and 813-5 had the longest stem length and 111311 had reduced length (Figure 1A). Genotypes 713-13 and 813-5 showed an increase in stem diameter, while genotype 1113-11 presented a smaller diameter, indicating that the rootstock may be less vigorous (Figure 1B). The internode length of peach cuttings was higher in genotypes 713-13 and 813-5 and the shortest lengths were observed 
in rootstocks from genotypes 1113-11, 813-15, 913-3 and 913-6, which indicates that these genotypes presented lower vegetative growth, avoiding competitions between vegetative and reproductive period (Figure 1C).
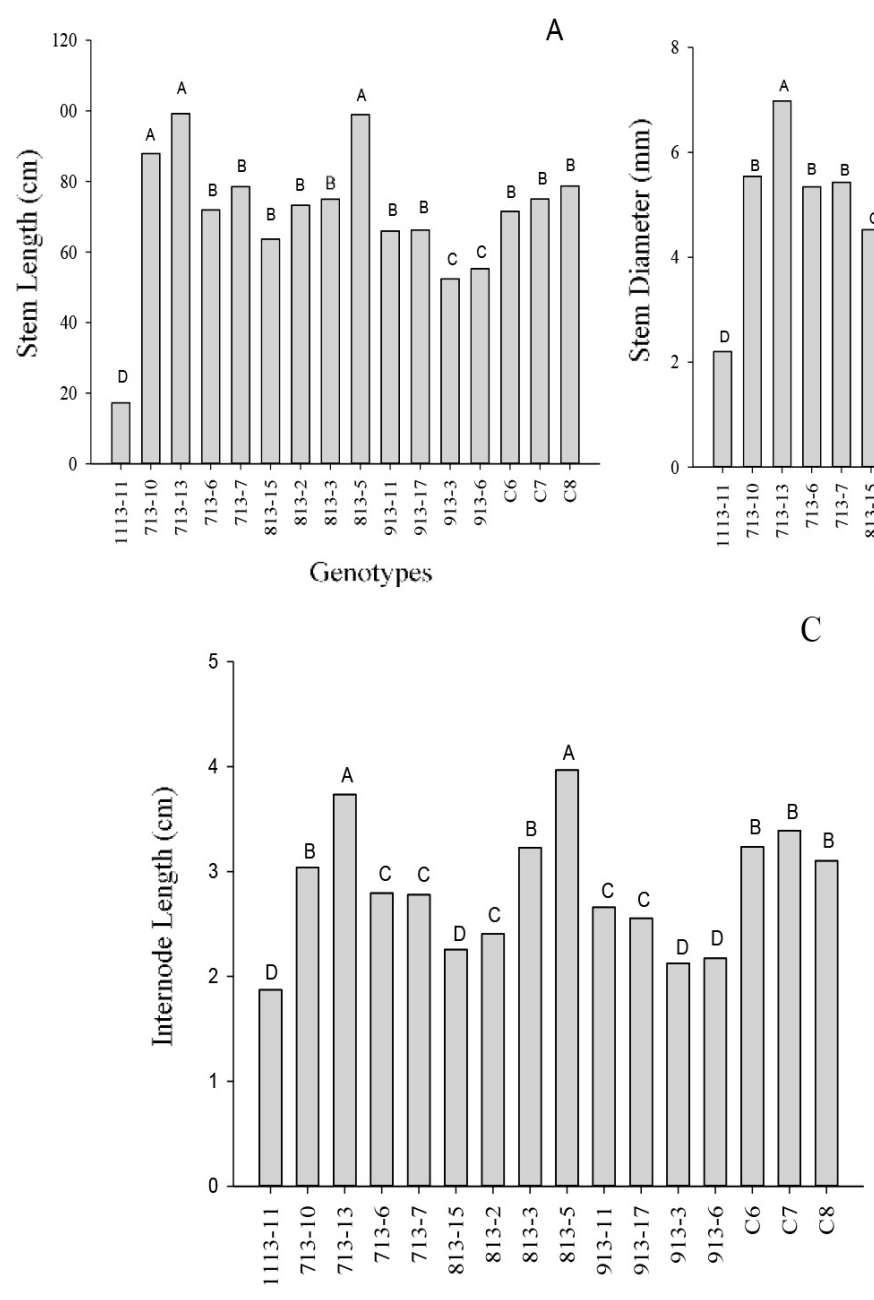

Genotypes

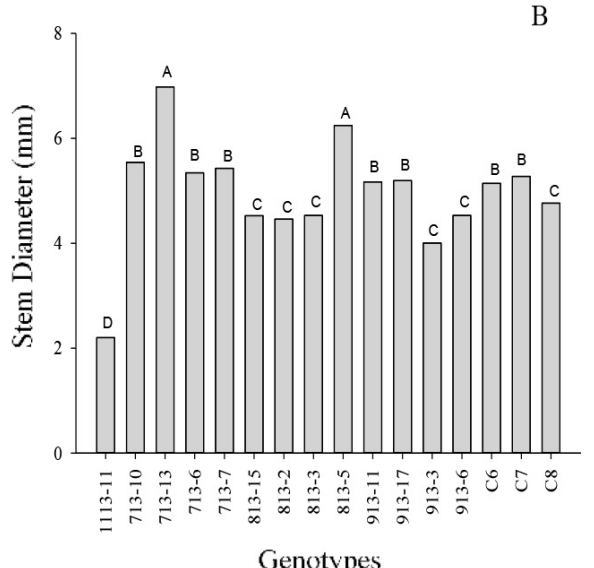

Genotypes

$\mathrm{C}$

Figure 1. Stem length (A), Stem diameter (B) and internode length (C) from seedlings of 16 peach rootstock genotypes from herbaceous cuttings.* Bars followed by the same capital letter do not differ from each other by the Scott-Knott test at the 5\% probability.

According to Galarça et al. (2013), plants with reduced length may have decreased productivity, however, there is the possibility of density, which would compensate for the decrease in productivity. Also, according to these authors, for both peach and citrus crops, it is possible to observe that smaller rootstocks showed good yield results.

The rootstock is capable of providing several characteristics that are absent in scion cultivar, such as resistance to pests and diseases, adaptability to climatic conditions and tolerance to saline or flooded soils, as well as modify the development of the scion cultivar decreasing crown size, which allows the establishment of orchards with high plant density (GAINZA et al., 2015). Rootstocks with these agronomic characteristics, especially the small size of the plant, are highly desirable in peach culture (SCHMITZ et al., 2014). The breeding program of the Federal University of Viçosa works to provide new options for peach rootstocks adapted to the growing region and with good interaction with the cultivar-canopy.
The density with the use of less vigorous rootstocks in peach tree contributes significantly to reduce and/or solve the problem of seasonality, low productivity and high perishability that peach tree culture faces, since among the peach tree producing countries, Brazil occupies the 21 st position. The reduction in internode length induces an increase in the number of flowers and fruits in the productive branches, a fact probably caused by the lower vegetative growth, which consequently leads to less competition between leaves and fruits (TOMAZ et al., 2010). The initial growth of peach cuttings is influenced by a combination of factors such as the nutrient absorption capacity of the soil and the length and volume of the root system (OLDONI et al., 2019). 
Genotype 1113-11 presented lower initial development, which is a desirable trait for densified cultivation and the rootstocks of the genotypes 713-13 and 813-5 were the ones that showed the highest initial development.

\section{Acknowledgements}

The authors thank the Coordination for the Improvement of Higher Education Personnel (CAPES) and National Council for Scientific and Technological Development (CNPq) for the financial support.

\section{References}

CRUZ, C.D. GENES - a software package for analysis in experimental statistics and quantitative genetics. Acta Scientiarum. Maringá, v.38, n.4, p.547-552, 2016.

FERRIANI, A.P.; MAYER, J.L.S.;ZUFFELLATO-RIBAS, K.C.; BONA, C.; KOEHLER, H.S.; DESCHAMPS, C.; CARPANEZZI, A.A.; OLIVEIRA, M.C. Estaquia e anatomia de vassourão-branco. Scientia Agraria, Curitiba, v.9, n.2, p 159-166, 2008.

GAINZA, F.; OPAZO, I.; GUAJARDO, V.; MEZA, P.; ORTIZ, M.; PINOCHET, J.; MUÑOZ, C. Rootstock breeding in Prunus species: Ongoing efforts and new challenges. Chilean Journal of Agricultural Research, Chillán, v. 75, p. 6-16, 2015.

GALARÇA, S.P.; FACHINELLO, J.C.; BETEMPS, D.L.; HOFFMANN, A.; MARODIN, G.A.B.; PRETTO, A.; NUNES, F.S.; DIAS, F.P. Crescimento e desenvolvimento de pessegueiros 'Chimarrita' e 'Maciel' sobre diferentes porta-enxertos e locais de cultivo. Ciência Rural, Santa Maria, v.43, n.2, p.219-224, 2013.

GONÇALVES, E.D.; MONTEIRO, V.; MAYER, N.A.; MOURA, P.H.A.; ALVARENGA, A.; ANTUNES, L.E.C.; TREVISAN, R.; PÁDUA, J.C. Desempenho de pessegueiro" BRS Libra" autoenraizado e enxertado sobre porta-enxertos clonais em Minas Gerais. Revista Brasileira de Ciências Agrárias, Recife, v.14, n.1, p.19, 2019.

LATTUADA, D.S.; SPIER, M.; SOUZA, P.V.D. Prétratamento com água e doses de ácido indolbutírico para estaquia herbácea de pitangueiras. Ciência Rural, Santa Maria, v.41, n.12, p.2073-2079, 2011.
MAYER, N.A.; PICOLOTTO, L.; BASTOS, P.V.; UENO, B.; ANTUNES, L.E.C. Estaquia herbácea de porta-enxertos de pessegueiro no final do verão. Semina: Ciências Agrárias, Londrina, v.35, n.4, p.1761-1771, 2014.

MULAMBA, N.N.; MOCK, J.J. Improvem (1)ent of yield potential of the Eto Blanco maize (Zea mays L.) population by breeding for plant traits. Egypt Journal of Genetics and Cytology, Alexandria, v.7, p.40-51, 1978.

OLDONI, C.M.; NIENOW, A.A.; SCHONS, J.; MAYER, N.A. Peroxidase activity and initial growth of 'Barbosa' peach on clonal rootstocks. Revista Brasileira de Fruticultura, Jaboticabal, v.41, n.6, e-086, 2019.

OLIVEIRA, J.A.A.; BRUCKNER, C. H.; SILVA, D. F. P.; SANTOS, C. E. M.; PENSO, G. A.; AQUINO, C. F. Estimation of genetic parameters and selection for rooting capacity in peach. Crop Breeding and Applied Biotechnology, Londrina, v.18, n.3, p.320-324, 2018.

PIZZATTO, M.; JÚNIOR, A.W.; LUCKMANN, D.; PIROLA, K.; CASSOL, D.A.; MAZARO, S.M. Influência do uso de AIB, época de coleta e tamanho de estaca na propagação vegetativa de hibisco por estaquia. Revista Ceres, Viçosa, MG, v.58, n.4, p.487-492, 2011.

ROSA, G.G.; ZANANDREA, I.; MAYER, N.A.; BIANCHI, V.J. Efeito do genótipo no enraizamento e aclimatação de estacas semilenhosas de porta enxertos de pessegueiro. Revista de Ciências Agroveterinárias, Lages, v.16, n.4, p.449-455, 2017a.

ROSA, G.G.; ZANANDREA, I.; MAYER, N.A.; BIANCHI, V.J. Propagação de porta-enxerto de Prunus spp. por estaquia: efeito do genótipo, do estádio de desenvolvimento do ramo e tipo de estaca. Revista Ceres, Viçosa, v.64, n.1, p.90-97, 2017 b.

SCHMITZ, J.D.; BIANCHI, V.J.; PASA, M.P.; SOUZA, A.L.K.; FACHINELLO, J.C. Vigor e produtividade do pessegueiro 'chimarrita' sobre diferentes porta-enxertos. Revista Brasileira de Agrociência, Pelotas, v.18, n.4, p.1-10, 2012.

SCHMITZ, J.D.; PASA, M.S.; FISCHER, D.L.O.; FACHINELLO, J.C.; BIANCHI, V.J. Desempenho de porta-enxertos em diferentes sistemas de cultivo na produção de mudas do pessegueiro Chimarrita. Revista Ceres, Viçosa, MG, v.61, n.2, p.155-160, 2014. 
SOARES, L.A.A.; BRITO, M.E.B.; FERNANDES, P.D.; DE LIMA, G.S.; SOARES FILHO, W.S.; DE OLIVEIRA, E.S. Growth of combinations of scion and citrus rootstocks under water stress in greenhouse. Revista Brasileira de Engenharia Agrícola e Ambiental, Campina Grande, v.19, n.3, p.211-218, 2015.

TIMM, C.R.F.; SCHUCH, M.W.; TOMAZ, Z.F.P.; MAYER, N.A. Enraizamento de miniestacas herbáceas de porta-enxertos de pessegueiro sob efeito de ácido indolbutírico. Semina: Ciências Agrárias, Londrina, v.36, n.1, p.135-140, 2015.
TOMAZ, Z.F.P.; LIMA, C.S.M.; GONÇALVES, M.A.; RUFATO, L.; RUFATO, A.D.R. Crescimento vegetativo, floração e frutificação efetiva do pessegueiro'Jubileu'submetido a diferentes comprimentos de interenxertos. Pesquisa Agropecuária Brasileira, Brasília, DF, v.45, n.9, p.973-979, 2010.

TOMAZ, Z.F.P.; SCHUCH, M.W.; PEIL, R.M.N.; FISCHER, D.L.O. Clonagem de porta-enxertos de pessegueiro por meio de miniestaquia em sistemas de cultivo sem solo. Revista Inova Ciência \& Tecnologia/ Innovative Science \& Technology Journal, Uberaba, v.2, n.1, p.29-37, 2016. 